William \& Mary Law School

William \& Mary Law School Scholarship Repository

Fall 2019

\title{
Out of the Quandary: Personal Jurisdiction Over Absent Class Member Claims Explained
}

A. Benjamin Spencer spencer@wm.edu

Follow this and additional works at: https://scholarship.law.wm.edu/facpubs

Part of the Civil Procedure Commons, Constitutional Law Commons, Courts Commons, Fourteenth Amendment Commons, and the Litigation Commons

\section{Repository Citation}

Spencer, A. Benjamin, "Out of the Quandary: Personal Jurisdiction Over Absent Class Member Claims Explained" (2019). Faculty Publications. 1962.

https://scholarship.law.wm.edu/facpubs/1962

Copyright c 2019 by the authors. This article is brought to you by the William \& Mary Law School Scholarship Repository.

https://scholarship.law.wm.edu/facpubs 


\title{
Out of the Quandary: Personal Jurisdiction Over Absent Class Member Claims Explained
}

\author{
A. Benjamin Spencer $\dagger$
}

\begin{abstract}
Since the Supreme Court's decision in Bristol-Myers Squibb Co. v. Superior Court of California, San Francisco County, litigants and lower courts have wrestled with the issue of whether a federal court must be able to exercise personal jurisdiction with respect to each of the claims asserted by absent class members in a class action and, if so, what standard governs that jurisdictional determination. This issue is rapidly coming to a head and is poised for inevitable resolution by the Supreme Court in the near future; multiple circuit courts have heard appeals from district courts that have reached varying conclusions on this point.

To provide guidance, both to the circuit courts facing this issue as well as to the Supreme Court once it is squarely presented with the question, this Article provides the proper analysis that courts should employ concerning the ability of federal courts to adjudicate the claims of absent class members. To wit: A federal court's authority to render a binding judgment against a defendant is currently constrained - by rule-to be coterminous with that of the courts of general jurisdiction in the fora in which they are located. Such constraints-which emanate from the Due Process Clause of the Fourteenth Amendment - mandate that the claims of absent members of a certified class must either arise out of or be related to the defendant's contacts with the forum, or be brought in a forum in which the defendant could be subjected to general jurisdiction. Prior to class certification, the claims of absent class members are not properly before the court and thus are not subject to dismissal; however, in anticipation of the requirement that only those class members whose claims can satisfy applicable Fourteenth Amendment standards may properly be included within the definition of the class that is certified,
\end{abstract}

\footnotetext{
${ }^{\dagger}$ Bennett Boskey Visiting Professor of Law, Harvard Law School; Justice Thurgood Marshall Distinguished Professor of Law, University of Virginia School of Law. The author is also a member of the Civil Rules Advisory Committee of the Judicial Conference of the United States. The views expressed in this Article are his own and do not represent official views of the Civil Rules Committee.
} 
a district court may strike from the complaint the allegations pertaining to the claims of absent class members who will be unable to meet these standards in response to a motion to strike. Or, as an alternative to that approach, defendants may opt to urge the district court to limit the definition of the certified class to the claims of absentees that meet Fourteenth Amendment constraints. To the extent the court certifies a class that includes the claims of absent class members that do not meet these constraints, the defendant may appeal the certification decision on that ground.

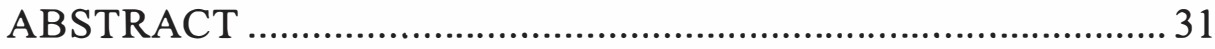

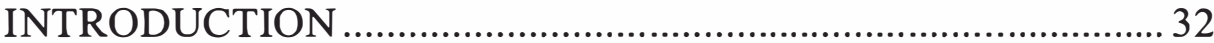

I.THE JURIDICAL STATUS OF UNNAMED CLASS MEMBERS

AND THEIR CLAIMS IN A PUTATIVE CLASS ACTION .. 35

II.DETERMINING A COURT'S JURISDICTION OVER THE CLAIMS OF ABSENT CLASS MEMBERS UPON CLASS CERTIFICATION

A. Rule 4(k)(1)(A) ................................................. 40

B. Rule 23 and the Fifth Amendment.................................4 44

C. The Fourteenth Amendment Standard ........................... 47

III.APPLYING THE CONSTRAINT: HOW COURTS MAY ENFORCE THE LIMITATIONS ON THEIR TERRITORIAL REACH OVER THE CLAIMS OF ABSENT CLASS

MEMBERS................................................................... 49

CONCLUSION

\section{INTRODUCTION}

In Bristol-Myers Squibb Co. v. Superior Court of California, San Francisco County, the U.S. Supreme Court held that a California state court could not exercise personal jurisdiction over a non-resident defendant based on the claims of non-California residents that did not arise out of and were not related to the California contacts of that defendant. ${ }^{1}$ Because Bristol-Myers involved a nationwide mass action directly filed in a California state court by the non-residents themselves, the Court's decision did not touch on the question of

1. 137 S. Ct. 1773, 1781 (2017) ("In order for a court to exercise specific jurisdiction over a claim, there must be an 'affiliation between the forum and the underlying controversy, principally, [an] activity or an occurrence that takes place in the forum State."' (quoting Goodyear Dunlop Tires Operations, S.A. v. Brown, 564 U.S. 915, 919 (2011))) (internal quotation marks and brackets omitted). 
whether state-court limits on personal jurisdiction applied to the claims of unnamed class members not injured in the forum, ${ }^{2}$ nor did its decision address whether the Fifth Amendment imposed similar restrictions on federal courts. ${ }^{3}$

The lower courts have quickly confronted the issues left open in Bristol-Myers, reaching varying results. Molock v. Whole Foods Market Group, Inc., is a putative class action filed in the U.S. District Court for the District of Columbia by past and present employees seeking wages they claimed were owed to them but not paid. ${ }^{4}$ Named class representatives included employees whose claims were not based on any conduct occurring within the District of Columbia, and the proposed class included persons whose claims had no connection with the forum. The district court dismissed the claims of the class representatives whose claims were not connected to D.C., but declined to exclude the unnamed putative class members whose claims were not connected to D.C., stating, "the court joins the other courts that have concluded that Bristol-Myers does not require a court to assess personal jurisdiction with regard to all non-resident putative class members." ${ }^{5}$ On September 25, 2019, the U.S. Court of Appeals for the D.C. Circuit heard argument in the appeal of the district court's decision in the case.

The U.S. District Court for the Northern District of Illinois has reached a contrary result. In Mussat v. IQVIA Inc., the plaintiff (an Illinois citizen) sued the defendant (a Delaware corporation with its principal place of business in Pennsylvania) in Illinois federal court under the Telephone Consumer Protection Act (TCPA), seeking to represent a geographically unrestricted, putative class of individuals with similar claims. ${ }^{6}$ The district court granted the defendant's motion to strike the claims of the non-Illinois absent class members from the definition of the class on the ground that applicable Fourteenth Amendment due process limitations "require[] a connection between the forum and the specific claims at issue" and "bars nationwide class

2. Id. at 1789 n.4 (Sotomayor, J., dissenting) ("The Court today does not confront the question whether its opinion here would also apply to a class action in which a plaintiff injured in the forum State seeks to represent a nationwide class of plaintiffs, not all of whom were injured there.").

3. Id. at 1783-84 ("In addition, since our decision concerns the due process limits on the exercise of specific jurisdiction by a State, we leave open the question whether the Fifth Amendment imposes the same restrictions on the exercise of personal jurisdiction by a federal court.").

4. 297 F. Supp. 3d 114, 120-21 (D.D.C. 2018).

5. Id. at 127 .

6. No. 17 C 8841, 2018 WL 5311903, at*1 (N.D. Ill. Oct. 26, 2018). 
actions in fora where the defendant is not subject to general jurisdiction."7 On September 27, 2019, the Seventh Circuit heard argument in the appeal of the district court's decision in the case. ${ }^{8}$

Given the importance of the class action device and the need for courts to know whether plaintiffs may bring nationwide class actions in a given jurisdiction, it is critical to resolve the question of whether federal courts ${ }^{9}$ may exercise personal jurisdiction over defendants with respect to the claims of unnamed class members ${ }^{10}$ whose claims are unconnected with the forum. In what follows, this Article will supply the doctrinal analysis that answers this question and provide guidance to courts regarding how they should proceed when such questions arise.

7. Id. at *5 (citing Bristol-Myers, $137 \mathrm{~S} . \mathrm{Ct}$. at 1780-81).

8. An additional case is headed for appellate review in the Fifth Circuit-an appeal of the decision in Cruson v. Jackson Nat'l Life Ins. Co., No. 4:16-CV-00912, 2018 WL 2937471, at *3 n.1 (E.D. Tex. June 12, 2018), in which the district court held that the defendant waived its personal jurisdiction challenge with respect to the claims of unnamed class members by not raising that objection until the class certification stage. Because of the court's waiver decision, the defendant's arguments under Bristol-Myers were not considered, and thus, the question addressed by this Article - the applicability of that case to class actions-may not be addressed by the circuit court.

9. This Article will confine itself to a discussion of the authority of federal courts to render binding judgments respecting the claims of absent class members, because it is in that context that the question most immediately presents itself in the cases mentioned, which are those most likely to immanently reach the U.S. Supreme Court. However, it is highly likely that the ability of state courts to render binding judgments over such claims will be constrained to a similar-if not greater--extent.

10. This Article need not thoroughly examine the question of whether a court must have personal jurisdiction over the claims of named class members and, if so, what standard should be applied. That question is manifestly resolved with reference to Bristol-Myers. Named plaintiffs must assert claims that have a connection with the forum to comport with due process. This is, in effect, the judgment reached by the district court in Molock. 297 F. Supp. 3d at 126 ("Here, fairness to Defendants counsels against exercising personal jurisdiction over the claims of [named class representatives], which simply have nothing to do with this forum. Accordingly, the claims of [named class representatives] against Defendants are dismissed for lack of specific personal jurisdiction."). See also Spratley v. FCA US LLC, 3:1 7-CV-0062, 2017 WL 4023348, at *7 (N.D.N.Y. Sept. 12, 2017) ("“I]n this case, the out-of-state [named] Plaintiffs have shown no connection between their claims and Chrysler's contacts with New York. Therefore, the Court lacks specific jurisdiction over the out-of-state Plaintiffs' claims."). Cf. Roy v. FedEx Ground Package Sys., Inc., 353 F. Supp. 3d 43, 56 (D. Mass. 2018) ("[T] his court ultimately does not find persuasive Plaintiffs' attempt to distinguish this case from Bristol-Myers on the basis that it is an FLSA collective action in federal court."). 


\section{THE JURIDICAL STATUS OF UNNAMED CLASS MEMBERS AND THEIR CLAIMS IN A PUTATIVE CLASS ACTION}

The starting point in this analysis is to specify the status of the absent members of a putative class and their claims. This is a vital first step because when a complaint is initially filed by a class representative on behalf of a class, whether the court may exercise personal jurisdiction over the claims of absent class members against the defendant depends on whether the absent class members and their claims are considered to be before that court. This issue has been articulated — unfortunately in my view - as tuming on whether absent class members are considered "parties" in the action. In Devlin v. Scardelletti, the Supreme Court stated that "[n]onnamed class members, however, may be parties for some purposes and not for others. The label 'party' does not indicate an absolute characteristic, but rather a conclusion about the applicability of various procedural rules that may differ based on context." 11 In what contexts has the Court engaged in this analysis and what can that tell us about absent class members' status for purposes of personal jurisdiction?

In the context of the diversity jurisdiction analysis for class actions, the Supreme Court has embraced seemingly divergent approaches. With respect to determining the amount in controversy in a class action, the Court has held that the claim of each class member-whether named or unnamed-must satisfy the amount-incontroversy requirement of the diversity statute-28 U.S.C. $\S 1332(a) .{ }^{12}$ Further, the Courthas held that where one class member's claim satisfies that requirement, the insufficient claims of other class members may not be aggregated to the sufficient claim to reach the jurisdictional amount. ${ }^{13}$ However, when assessing diversity of citizenship for class actions, the Court has indicated that the citizenship of only the named class representatives is to be taken into

11. 536 U.S. 1, 9-10 (2002).

12. Snyder v. Harris, 394 U.S. 332, 336 (1969) ("When two or more plaintiffs, having separate and distinct demands, unite for convenience and economy in a single suit, it is essential that the demand of each be of the requisite jurisdictional amount." (quoting Troy Bank v. G. A. Whitehead \& Co., 222 U.S. 39, 40 (1911))).

13. Zahn v. Int'l Paper Co., 414 U.S. 291, 301 (1973) ("Each plaintiff in a Rule 23(b)(3) class action must satisfy the jurisdictional amount, and any plaintiff who does not must be dismissed from the case-'one plaintiff may not ride in on another's coattails."' (quoting Zahn v. Int'l Paper Co., 469 F.2d 1033, 1035 (2d Cir. 1972))). 
account. ${ }^{14}$ These varying treatments of absent class members and their claims have been regarded - even by the Supreme Court itself-as supportive of the notion that absent class members "may be parties for some purposes and not for others." ${ }^{15}$ Not so.

Careful analysis of the reasoning underlying these divergent approaches to assessing the twin components of the diversity jurisdiction statute reveals that the Supreme Court is not-in either case-treating unnamed class members as parties joined in the action. The diversity of citizenship rule for class actions-which is articulated principally in Supreme Tribe of Ben-Hur v. Cauble-was an application of the then-extant doctrine of ancillary jurisdiction; having attained jurisdiction over the claim of a diverse class representative against a defendant, a district court could exercise ancillary jurisdiction over the claims of members of the class who were not diverse from the defendant. ${ }^{16}$ Tuming to the amount-in-controversy requirement for class actions, the rule against aggregating class claims-announced in Snyder v. Harris--did not depend on the conclusion that the absent class members were parties joined in the action and thus their claims had to be assessed under existing nonaggregation rules. Rather, the Court indicated that once there is a judgment for the entire class, the claims of absent class members will be included in that judgment, which will mean that the "matter in controversy" under 28 U.S.C. $\S 1332$ (a) "now encompasses all the claims of the entire class," not just those of the named class representative. ${ }^{17}$ The Court then concluded that, although "it was in

14. Supreme Tribe of Ben-Hur v. Cauble, 255 U.S. 356, 365-66 (1921). See also Snyder, 394 U.S. at 340 ("Under current doctrine, if one member of a class is of diverse citizenship from the class' opponent, and no nondiverse members are named parties, the suit may be brought in federal court even though all other members of the class are citizens of the same State as the defendant and have nothing to fear from trying the lawsuit in the courts of their own State.").

15. Devlin, 536 U.S. at 10.

16. 255 U.S. at 365 ("The right of the court to proceed to decree between the appellants and the new parties [non-diverse unnamed class members] did not depend upon difference of citizenship; because, the bill having been filed by the original complainants on behalf of themselves and all other creditors choosing to come in and share the expenses of the litigation, the court, in exercising jurisdiction between the parties, could incidentally decree in favor of all other creditors coming in under the bill. Such a proceeding would be ancillary to the jurisdiction acquired between the original parties, and it would be merely a matter of form whether the new parties should come in as co-complainants, or before a master, under a decree ordering a reference to prove the claims of all persons entitled to the benefit of the decree." (quoting Stewart v. Dunham, 115 U.S. 61, 64 (1885))).

17. Snyder, 394 U.S. at 337. 
joinder cases of this very kind that the doctrine that distinct claims could not be aggregated was originally enunciated," there was "certainly no reason to treat [class actions] differently from joined actions for purposes of aggregation." 18

Thus, with respect to subject matter jurisdiction, the Court has treated the claims of absent putative class members as follows: (1) There is ancillary jurisdiction over the claims of nondiverse absent class members; and (2) the claims of class members to be included in the judgment form part of the "matter in controversy" for purposes of an analysis under $\S 1332$, requiring that each independently meet the required amount in controversy. Congress disrupted this state of affairs to some extent, of course, when it enacted the supplemental jurisdiction statute-28 U.S.C. $\S 1367$. That statute embraced the idea that there could be ancillary (now "supplemental") jurisdiction over the claims of nondiverse class members but rejected the limitation imposed by Snyder on the claims of class members not satisfying the amount-in-controversy requirement of the diversity statute. Now, supplemental jurisdiction is available for such claims. ${ }^{19}$

In Devlin v. Scardelletti, the Court faced the question of whether unnamed class members could appeal the approval of a class settlement, given that they were not class representatives and had not intervened in the suit. The Court concluded:

$[\mathrm{N}]$ onnamed class members are parties to the proceedings in the sense of being bound by the settlement. It is this feature of class action litigation that requires that class members be allowed to appeal the approval of a settlement when they have objected at the faimess hearing. To hold otherwise would deprive nonnamed class members of the power to preserve their own interests in a settlement that will ultimately bind them, despite their expressed objections before the trial court. ${ }^{20}$

18. Id.

19. Exxon Mobil Corp. v. Allapattah Servs., Inc., 545 U.S. 546, 560 (2005) ("Nothing in the text of $\S 1367(\mathrm{~b})$, however, withholds supplemental jurisdiction over the claims of plaintiffs . . certified as class-action members pursuant to Rule $23 \ldots$ The natural, indeed the necessary, inference is that $\S 1367$ confers supplemental jurisdiction over claims by . . . Rule 23 plaintiffs.").

20. 536 U.S. at 10 . 
But this was a limited holding recognizing the standing of absent class members to challenge a settlement that would bind them as members of the class and represent a final decision on their claims. The Court did not thereby convert absent class members into named parties in the litigation; rather, it indicated that "[w]e have never ... restricted the right to appeal to named parties to the litigation," and concluded that unnamed class members do not have to be named parties in the action to have the ability to appeal a final determination of their rights. ${ }^{21}$ Devlin should not be read as an example of treating absent class members as parties to the action or the litigation, but as the Court extending to those members a right to appeal the approval of settlements that will bind them. ${ }^{22}$

How do these cases and other Supreme Court precedent inform our understanding of the status of unnamed class members in the personal jurisdiction context? No Supreme Court case regards absent class members as parties joined in the action filed by a putative class representative. ${ }^{23}$ Indeed, "until certification there is no class action but merely the prospect of one." ${ }^{24}$ This means that at the point of filing, the action stands as one between the named class representatives and the defendant named in the complaint; the claims of absent class members are not yet before the court. It necessarily follows that when determining whether there is personal jurisdiction over the defendant with respect to claims asserted by the named plaintiffs in a putative class action, the only claims to be assessed by the court are those of the class representatives. And that assessment is to be done in the

21. Id. at 7.

22. This is not to say that the Devlin majority was correct in extending the right of appeals to absent class members. The majority makes a sound policy argument that given the inability to opt out of the settlement in what was a class action under Rule 23(b)(1), a right of appeal was the only means an unnamed class member had to protect himself from being bound. Id. at 10. However, Justice Scalia, writing in dissent, makes a compelling argument that absent class members may simply intervene in the action to become parties and assert their right to appeal. Id. at 2223 (Scalia, J., dissenting).

23. See, e.g., Am. Pipe \& Constr. Co. v. Utah, 414 U.S. 538, 550 (1974) ("A federal class action is no longer 'an invitation to joinder' but a truly representative suit designed to avoid, rather than encourage, unnecessary filing of repetitious papers and motions."). See also FED. R. CrV. P. 23(a)(1) (permitting a class action "only if the class is so numerous that joinder of all members is impracticable") (emphasis added).

24. Police \& Fire Ret. Sys. v. IndyMac MBS, Inc., 721 F.3d 95, 112 n.22 (2d Cir. 2013) (quoting Morlan v. Universal Guar. Life Ins. Co., 298 F.3d 609, 616 (7th Cir. 2002)). 
ordinary case under the auspices of Rule $4(\mathrm{k})(1)(\mathrm{A}),{ }^{25}$ which requires that the federal district courts respect the Fourteenth Amendment due process limitations imposed on the territorial reach of their respective host states. ${ }^{26}$

\section{DETERMINING A COURT'S JURISDICTION OVER THE CLAIMS OF ABSENT CLASS MEMBERS UPON CLASS CERTIFICATION.}

Once a class is certified, the district court assumes-under Rule 23-the ability to render a binding judgment with respect to all members of that class as the court has defined it-named and unnamed. This comports with the due process rights of the unnamed class members because they are afforded notice of the action and the ability to opt out of the class. ${ }^{27}$ The question is whether the defendant retains any due process protections that are triggered by the certification decision with respect to the claims of unnamed class members. In other words, once the claims of absent class members are certified and are now before the court for its authoritative judgment, must that court be able to exercise personal jurisdiction over the defendant for each of those claims?

Certainly, there is nothing more fundamental to judicial authority than the principle that a court must have jurisdiction over a defendant (and the subject matter of the dispute) to render a binding judgment against it. ${ }^{28}$ In Phillips Petroleum Co. v. Shutts, the Supreme

25. FED. R. CIV. P. 4(k)(1)(A); Daimler AG v. Bauman, 571 U.S. 117, 125 (2014) ("Federal courts ordinarily follow state law in determining the bounds of their jurisdiction over persons.") (citing FED. R. CIV. P. 4(k)(1)(A)).

26. When the host jurisdiction is the District of Columbia, that concerns jurisdiction in a federal enclave through courts whose actions are constrained by the Due Process Clause of the Fifth Amendment, not the Fourteenth Amendment. However, the long-arm statute of the District of Columbia, D.C. Code § 13-423, limits personal jurisdiction against non-residents based on claims arising out of contacts with the District of Columbia, consistent with the constitutional limitations imposed by the Fifth Amendment. Jackson v. George, 146 A.3d 405, 413 (D.C. 2016) ("This court has repeatedly reaffirmed that the transacting business provision of the District's Long Arm Statute is coextensive with the due process clause of the Fifth Amendment. In other words, the defendant must have minimum contacts with the forum so that exercising personal jurisdiction over it would not offend traditional notions of fair play and substantial justice.") (emphasis added) (citations and internal quotation marks omitted).

27. Phillips Petroleum Co. v. Shutts, 472 U.S. 797, 812 (1985).

28. Pennoyer v. Neff, 95 U.S. 714, 733 (1877) ("Since the adoption of the Fourteenth Amendment to the Federal Constitution, the validity of such judgments 
Court indicated that a court adjudicating the claims of absent class members has to have jurisdiction over those claims and that such jurisdiction is constrained by due process. The issue the Shutts Court faced was the nature of these due process constraints vis-à-vis unnamed class members, not whether any due process constraints existed at all. Thus, as to the foundational question of whether due process supplies any limit on the ability of a court to render a binding judgment with respect to absent class members or defendants who face the claims of absent class members, the Supreme Court has indicated that the answer is yes: "The Fourteenth Amendment does protect 'persons,' not 'defendants,' however, so absent plaintiffs as well as absent defendants are entitled to some protection from the jurisdiction of a forum State which seeks to adjudicate their claims." 29

The more challenging questions are what is the specific source and content of this protection that the Court has recognized? Beginning with the source question first, because we are concerned here with the jurisdictional reach of federal courts adjudicating class actions, the only possibilities are (1) Rule 4(k)(1)(A) and the Fourteenth Amendment's Due Process Clause; or (2) Rule 23 and the Due Process Clause of the Fifth Amendment.

\section{A. Rule 4(k)(1)(A)}

Rule $4(\mathrm{k})(1)(\mathrm{A})$ would appear to have the strongest claim because the territorial reach of federal district courts is tied by that rule - and, derivatively, by the Fourteenth Amendment- to the reach of their respective host states, unless there is an alternate provision of Rule 4(k) that applies. ${ }^{30}$ Those alternate provisions give a nod to the

may be directly questioned, and their enforcement in the State resisted, on the ground that proceedings in a court of justice to determine the personal rights and obligations of parties over whom that court has no jurisdiction do not constitute due process of law.").

29. Shutts, 472 U.S. at 811.

30. Rule 4(k) supplies the applicable rule of personal jurisdiction in all cases in federal district court, regardless of whether the court's subject matter jurisdiction is based on diversity jurisdiction or federal question jurisdiction. See, e.g., Walden v. Fiore, 571 U.S. 277 (2014) (applying Rule 4(k)(1)(A) to a Bivens action); Omni Capital Int''l v. Rudolf Wolff \& Co., 484 U.S. 97, 104 (1987) ("Today, service of process in a federal action is covered generally by Rule 4 of the Federal Rules of Civil Procedure."). None of the analysis of the authority of federal district courts to adjudicate the claims of unnamed class members depends on whether those claims are based on state or federal law, except to the extent there is a federal law that 
ability of federal courts to exercise personal jurisdiction on a broader scale - to the limits of the Due Process Clause of the Fifth Amendment-which requires only that a defendant have minimum contacts with the United States as a whole. ${ }^{31}$ Thus, a party joined under Rule 14 or 19 served within 100 miles of the courthouse where the action is pending (and within the United States) is subject to the court's jurisdiction, regardless of whether that party has minimum contacts with the forum state. ${ }^{32}$ When Congress authorizes nationwide service of process in a federal statute, Rule $4(k)(1)(C)$ recognizes that jurisdiction can be proper on that basis. ${ }^{33}$ And if there is no state with which the defendant has sufficient minimum contacts to support personal jurisdiction in a federal question case, Rule $4(k)(2)$ permits the federal court to exercise jurisdiction consistent with the limits of

authorizes personal jurisdiction on a nationwide basis. See FED. R. CIV. P. 4(k)(1)(C).

31. See, e.g., Livnat v. Palestinian Auth., 851 F.3d 45, 55 (D.C. Cir. 2017) ("The only difference in the personal-jurisdiction analysis under the two Amendments is the scope of relevant contacts: Under the Fourteenth Amendment, which defines the reach of state courts, the relevant contacts are state-specific. Under the Fifth Amendment, which defines the reach of federal courts, contacts with the United States as a whole are relevant."); see also Republic of Panama v. BCCI Holdings (Lux.) S.A., 119 F.3d 935, 946--47 (11th Cir. 1997) ("[A] defendant's contacts with the forum state play no magical role in the Fifth Amendment analysis .... Thus, determining whether litigation imposes an undue burden on a litigant cannot be determined by evaluating only a defendant's contacts with the forum state. A court must therefore examine a defendant's aggregate contacts with the nation as a whole rather than his contacts with the forum state in conducting the Fifth Amendment analysis." (footnote omitted)); United Elec., Radio \& Mach. Workers v. 163 Pleasant St. Corp., 960 F.2d 1080, 1085 (1st Cir. 1992) ("[T]he Constitution requires only that the defendant have the requisite 'minimum contacts' with the United States, rather than with the particular forum state . . ..”); United States v. De Ortiz, 910 F.2d 376, 382 (7th Cir. 1990) (indicating that Fif th Amendment due process is satisfied where the defendant has "sufficient contacts with the United States as a whole rather than any particular state or other geographic area"). The scope of territorial jurisdiction under the Fifth Amendment is discussed generally in A. Benjamin Spencer, The Territorial Reach of Federal Courts, 71 FLA. L. REV. 979 (2019).

32. FED. R. CIV. P. 4(k)(1)(B). Rule 4(k)(1)(B) limits its reach to service "within a judicial district of the United States" because service outside of the United States-regardless of whether such service occurred within 100 miles of a federal district courthouse - would not be able to establish jurisdiction consistent with the limits of the Fifth Amendment, which requires minimum contacts with (and thus service inside of) the United States.

33. FED. R. CIV. P. 4(k)(1)(C). 
the Constitution-which are the Fifth Amendment's due process constraints. ${ }^{34}$

However, in the class action context, none of the other provisions of Rule $4(\mathrm{k})$ are relevant. The claims of absent class members are not before the court at the outset of the action when service is made and those members are not joined in the action under Rule 14 or 19 , making Rule $4(\mathrm{k})(1)(B)$ inapplicable. Neither is there a federal statute that authorizes nationwide service of process for class actions, making Rule $4(\mathrm{k})(\mathrm{l})(\mathrm{C})$ inapplicable. Rule $4(\mathrm{k})(2)$ 's provision has no relevance to class actions asserting state law claims and is ordinarily not available due to the amenability of most defendants to specific jurisdiction in a particular U.S. state. It would seem, then, that Rule 4(k)(1)(A) remains the virtually only rule setting forth the jurisdictional reach of a district court presented with a class action.

It is certainly true that Rule $4(\mathrm{k})(1)(\mathrm{A})$ is the relevant rule governing the assertion of personal jurisdiction over the defendant for the claims of named class representatives, as those are the claims included in the complaint that is served with the summons on the defendant. At that time, the claims of unnamed class members-as discussed above-are not before the court. Once the court certifies a class that includes the claims of absent class members, however, that is when the due process constraints on a court's authority over unnamed class members and their claims against the defendant come into play. ${ }^{35}$ But practice under Rule 23 does not require that the summons and complaint be re-served on the defendant once a class is certified. Does this mean that there is technically no vehicle through which Rule 4(k)(1)(A) may be reapplied to govern the territorial reach of the court over the claims of absent class members now subject to its judgment?

The Appellees in Whole Foods Market Group, Inc. v. Molock certainly thought so, making this argument both in their brief and at

34. FED. R. CIV. P. 4(k)(2).

35. Phillips Petroleum Co. v. Shutts, 472 U.S. 797, 811 (1985) ("The Fourteenth Amendment does protect 'persons,' not 'defendants,' however, so absent plaintiffs as well as absent defendants are entitled to some protection from the jurisdiction of a forum State which seeks to adjudicate their claims."). See also William Rubenstein, 2 NEWBERG ON CLASS ACTIONS, $\S 6: 26$ (5th ed.) ("If the class prevails in the case, the goal is a binding judgment over the defendant as to the claims of the entire nationwide class - and the deprivation of the defendant's property accordingly. Such a proposed class-wide deprivation triggers a defendant's right to class-wide due process, that is, its right to ensure the requisite territorial connection between it and the court as to the full scope of its liability."). 
oral argument before the D.C. Circuit. ${ }^{36}$ But this is pure nonsense. Once a defendant has appeared in a case in response to the original service of the complaint, all subsequent pleadings are served on the defendant under Rule 5(a)(1). ${ }^{37}$ This means, for example, that an amended pleading asserting new claims need not be re-served under Rule 4. ${ }^{38}$ There is no question that-notwithstanding that such amended complaints are not served with a summons under Rule 4new claims appearing in amended complaints must satisfy the jurisdictional constraints imposed by Rule 4(k); courts regularly apply Rule $4(\mathrm{k})(\mathrm{l})(\mathrm{A})$ limitations to the claims appearing in amended complaints. $^{39}$ It would be preposterous to suggest that because amended complaints are served under Rule 5 they may evade the restrictions applicable to claims contained within complaints served under Rule 4, subject only to the limits of the Fifth Amendment's due process clause. Were such the case, the ability to amend would provide a gaping loophole to the ordinary territorial restrictions on federal court jurisdiction that Rule 4(k) imposes.

Counsel for the Appellee in Mussat v. IQVIA Inc. attempted to make this point at oral argument before the Seventh Circuit, but was rebuffed by the judges of the panel, who argued that Rule $4(\mathrm{k})(\mathrm{l})(\mathrm{A})$ was applicable to claims added by amendment because the original named plaintiff - who served the summons and complaint under Rule 4 - was the party asserting the new claims. ${ }^{40}$ What should have been pointed out to the panel is that when a plaintiff amends its complaint to add new plaintiffs under Rule 20, or when new plaintiffs intervene in an action under Rule 24 , neither of these parties is required to serve

36. Corrected Brief of Plaintiffs-Appellees at 33 n.9, Whole Foods Mkt. Grp., Inc. v. Molock (No. 18-7162), (D.C. Cir. Apr. 2, 2019) ("Service of process on the defendant by unnamed class members has never been required under Rule 4, Rule 23 , or any other law. Rule 4 therefore does not limit federal courts' jurisdiction over unnamed class members' claims.").

37. FED. R. CIV. P. 5(a)(1)(B) (providing for service of "a pleading filed after the original complaint" in accordance with the various methods identified in Rule $5(\mathrm{~b}))$.

38. See, e.g., Emp. Painters' Tr. v. Ethan Enters., Inc., 480 F.3d 993, 999 (9th Cir. 2007) ("Although the parties and the district court assumed - for reasons not explained - that Rule 4 governed service of the amended complaint, that is not so. Instead, it is Rule 5 that was applicable.").

39. See, e.g., Tamburo v. Dworkin, 601 F.3d 693, 700-01 (7th Cir. 2010) (applying Rule 4(k)(1)(A) to determine the ability of the district court to exercise personal jurisdiction over claims asserted in a "Sixth Amended Complaint").

40. Oral Argument at 27:53-28:00, Mussat v. IQVIA Inc. (7th Cir. Sept. 27, 2019) (No. 19-1204), http://media.ca7.uscourts.gov/sound/2019/pr.19-1204.191204_09_27_2019.mp3. 
process on the defendant under Rule 4. Instead, their claims are introduced in the action either through an amendment under Rule 15 (adding a plaintiff under Rule 20) or a motion to intervene under Rule 24 , both of which are communicated to the defendant under the auspices of Rule $5,{ }^{41}$ not Rule $4 .{ }^{42}$ Notwithstanding that, the personal jurisdiction limitations of the district court that are imposed by Rule $4(\mathrm{k})$ remain the operative constraints that district courts apply to these new claims by newly joined parties. It thus cannot be gainsaid that the territorial reach of federal courts over claims added to the action after the initial service of the summons is defined by Rule 4(k), even though none of those claims are served on defendants under Rule 4. It follows, then, that if there is any regulatory source of the territorial limits on a federal district court's authority to adjudicate the claims of absent members of a certified class in a way that binds defendants, it must emanate from Rule 4(k).

\section{B. Rule 23 and the Fifth Amendment}

Indeed, no other plausible candidate for the source of such jurisdictional constraints can be found. It cannot be that Rule 23 itself provides the relevant jurisdictional rule. Nothing in the language of the rule addresses the personal jurisdiction of district courts over the claims of absent class members included in a certified class. As a rule of procedure promulgated under the Rules Enabling Act (REA), ${ }^{43}$

41. FED. R. CIV. P. 5 (indicating that "a pleading filed after the original complaint" may be served by any of the methods enumerated in Rule 5(b); FED. R. CrV. P. 24(c) ("A motion to intervene must be served

on the parties as provided in Rule 5."). See also, e.g., Bonita Packing Co. v. O’Sullivan, 165 F.R.D. 610, 612-13 (C.D. Cal. 1995) ("A federal court does not have jurisdiction over a defendant unless the defendant has been served properly ... under Fed.R.Civ.P. 4. . . A summons and complaint in intervention, however, may be served in accordance with Rule 5(b) ...."). Rule 24(c) has abrogated the understanding that the Supreme Court had prior to the enactment of the Federal Rules of Civil Procedure that intervening plaintiffs must serve their claims on defendants in accord with ordinary requirements of service of process. See In re Ind. Transp. Co., 244 U.S. 456, 458 (1917) (Holmes, J.) ("The new claimants are strangers and must begin their action by service just as if no one had sued the defendant before.").

42. See, e.g., Johnson v. Kraft Foods N. Am., Inc., No. 05-2093-JWL-DJW, 2006 WL 8429267, at *3 (D. Kan. Apr. 3, 2006) ("[T]he Court finds joinder of the proposed plaintiffs under Rule 20 (a) is appropriate; thus, Plaintiff's Motion to Amend Complaint is granted. Plaintiff shall electronically file and serve the First Amended Complaint .....") (emphasis added) (citation omitted).

43. 28 U.S.C. $\S 2072$. 
Rule 23 is a procedural device that merely "allows willing plaintiffs to join their separate claims against the same defendants in a class action .... [L]ike traditional joinder, it leaves the parties' legal rights and duties intact and the rules of decision unchanged." 44

Additionally, because Rule 4(k) expressly addresses the territorial reach of federal courts, there is no warrant for federal courts to read into Rule 23 a federal common law rule permitting a kind of pendent party personal jurisdiction ${ }^{45}$-limited only by the national contacts constraints imposed by the Fifth Amendment ${ }^{46}$ - over the claims of unnamed class members to effectuate the purposes of Rule 23. Although, in another context, the Court has read into Rule 23 the ability to toll the running of applicable limitations periods for absent class members subsequently choosing to pursue their claims individually, ${ }^{47}$ this was an articulation of an equitable tolling rule in the absence of any language in Rule 23 or elsewhere that addressed the matter. The authority of federal courts to exercise personal jurisdiction over defendants is not an analogous setting. Given the provisions addressing jurisdiction in several distinct circumstances in Rule 4(k) - none of which explicitly speak of class actions - and the failure of Congress to enact a nationwide service-of-process provision for class actions, it would be inappropriate for the Court to read Rule 23 to contain such a provision by implication; expressio unius est exclusio alterius. As the Court aptly put it in Omni Capital International, Ltd. v. Rudolph Wolff \& Co., when confronted with a request to imply nationwide jurisdiction into Section 22 of the Commodity Exchange Act (CEA):

Section 22, however, is silent as to service of process. This contrasts sharply with the other enforcement

44. Shady Grove Orthopedic Assocs., P.A. v. Allstate Ins. Co., 559 U.S. 393, 408 (2010) (Scalia, J.). See generally A. Benjamin Spencer, Substance, Procedure, and the Rules Enabling Act, 66 UCLA L. REV. 654 (2019) (discussing the limits imposed on rules promulgated under the Rules Enabling Act).

45. The contemporary doctrine of pendent personal jurisdiction as embraced by the circuit courts is that "where a federal statute authorizes nationwide service of process, and the federal and state-law claims derive from a common nucleus of operative fact, the district court may assert personal jurisdiction over the parties to the related state-law claims even if personal jurisdiction is not otherwise available." Charles Schwab Corp. v. Bank of Am. Corp., 883 F.3d 68, 88 (2d Cir. 2018) (quoting IUE AFL-CIO Pension Fund v. Herrmann, 9 F.3d 1049, 1056 (2d Cir. 1993)).

46. See supra note 31 (citing cases articulating the national contacts standard applicable under the Fif th Amendment).

47. Am. Pipe \& Constr. Co. v. Utah, 414 U.S. 538 (1974). 
provisions of the CEA, on which Omni asks us to rely. We find it significant that Congress expressly provided for nationwide service of process in those sections but did not do so in the new $\S 22$. It would appear that Congress knows how to authorize nationwide service of process when it wants to provide for it. That Congress failed to do so here argues forcefully that such authorization was not its intention. ${ }^{48}$

Further, even if implying a nationwide jurisdictional reach on a pendent personal jurisdiction theory were permissible, ${ }^{49}$ it could not be justified by a need to effectuate the policy behind Rule 23 of facilitating class actions. U.S.-based defendants will always be suable in their home jurisdictions. ${ }^{50}$ Foreign defendants can be sued by classes in federal courts located in those states with which they have minimum contacts, and then those actions can be subsequently consolidated and transferred to a single district under the multidistrict litigation statute, 28 U.S.C. $\S 1407$, if the respective classes raise common questions of fact. ${ }^{51}$ Nationwide jurisdiction in every federal

48. 484 U.S. 97,106 (1987).

49. Note that the Supreme Court expressly rejected the attempt to permit a state court to exercise pendent party personal jurisdiction over claims unconnected with the forum in Bristol-Myers Squibb:

As we have explained, "a defendant's relationship with a ... third party, standing alone, is an insufficient basis for jurisdiction." This remains true even when third parties (here, the plaintiffs who reside in Califomia) can bring claims similar to those brought by the nonresidents. Nor is it sufficient-or even relevant-that BMS conducted research in California on matters unrelated to Plavix. What is neededand what is missing here-is a connection between the forum and the specific claims at issue.

Bristol-Myers Squibb Co. v. Superior Ct. of Cal., S.F. Cty., 137 S. Ct. 1773, 1781 (2017) (citation omitted).

50. Daimler AG v. Bauman, 571 U.S. 117, 122 (2014).

51. 28 U.S.C. $\$ 1407$ (a) ("When civil actions involving one or more common questions of fact are pending in different districts, such actions may be transferred to any district for coordinated or consolidated pretrial proceedings."). Personal jurisdiction is not ordinarily a problem for a transferee court receiving actions from other federal districts under $\S 1407$ (the MDL statute). See In re FMC Corp. Patent Litig., 422 F. Supp. 1163, 1165 (J.P.M.L. 1976) ("Transfers under Section 1407 are simply not encumbered by considerations of in personam jurisdiction and venue. . . . Following a transfer, the transferee judge has all the jurisdiction and powers over pretrial proceedings in the actions transferred to him that the transferor judge would have had in the absence of transfer."). See also Howard v. Sulzer Orthopedics, Inc., 382 F. App'x 437, 442 (6th Cir. 2010) ("The MDL statute (28 U.S.C. $\S 1407$ ) is, in fact, legislation 'authorizing the federal courts to exercise nationwide personal 
district is hardly necessary to vindicate the interests of Rule 23 . If these vehicles for asserting class actions are deemed by Congress to be insufficient, it well knows how to remedy the situation through legislation $^{52}$ or a direct revision of the Federal Rules. ${ }^{53}$

\section{The Fourteenth Amendment Standard}

Now that we have established that there must be personal jurisdiction over a defendant with respect to the claims of absent class members, and that Rule 4(k) determines the scope of a federal district court's jurisdictional reach over such claims, stating the content of the standard that courts must use to guide their jurisdictional analysis is straightforward. The Fourteenth Amendment's due process constraints-made operative in federal court by Rule 4(k)(1)(A) "limit[] the power of a state court to render a valid personal judgment against a nonresident defendant." ${ }^{\circ 4}$ The Supreme Court has repeatedly stressed that this limitation means-outside the general jurisdiction context-"there must be 'an affiliation between the forum and the underlying controversy, principally, [an] activity or an occurrence that takes place in the forum State" "\$55 and is therefore subject to the State's regulation. More directly, the Court has stated that "[i]n order for a state court to exercise specific jurisdiction, 'the suit' must 'aris[e] out of or relat [e] to the defendant's contacts with the forum." 56

Although the Court has also emphasized that "a variety of interests" are relevant to the specific jurisdiction analysis-with the "primary concern" being "the burden on the defendant"-these

jurisdiction.'”) (quoting In re “Agent Orange” Prod. Liab. Litig., 818 F.2d 145, 163 (2d Cir. 1987)).

52. See, e.g., 28 U.S.C. $\S 2361$ (providing for nationwide service of process in statutory interpleader actions under 28 U.S.C. $\S 1335$ ). See also, e.g., 15 U.S.C. $\S$ 22 (Clayton Act) ("[A]ll process in such cases may be served in the district of which it is an inhabitant, or wherever it may be found.").

53. If an alternate jurisdictional rule were desired for class actions, the Civil Rules Advisory Committee, or Congress, could amend Rule $4(\mathrm{k})$ by adding the following language to what would become Rule 4(k)(3):

(3) Claims of Unnamed Class Members. For claims asserted by unnamed members of a class action, serving a summons or filing a waiver of service establishes personal jurisdiction over a defendant if exercising jurisdiction is consistent with the United States Constitution and laws.

54. World-Wide Volkswagen Corp. v. Woodson, 444 U.S. 286, 291 (1980).

55. Bristol-Myers Squibb Co. v. Superior Ct. of Cal., S.F. Cty., 137 S. Ct. 1773, 1781 (2017) (quoting Goodyear Dunlop Tires Operations, S.A. v. Brown, 564 U.S. 915, 919 (2011)).

56. Id. at 1780 (quoting Daimler AG v. Bauman, 571 U.S. 117, 127 (2014)). 
considerations cannot control the analysis because "restrictions on personal jurisdiction ... 'are a consequence of territorial limitations on the power of the respective States." ${ }^{57}$ As a result, as stated recently by the Court in Bristol-Myers,

[E]ven if the defendant would suffer minimal or no inconvenience from being forced to litigate before the tribunals of another State; even if the forum State has a strong interest in applying its law to the controversy; even if the forum State is the most convenient location for litigation, the Due Process Clause, acting as an instrument of interstate federalism, may sometimes act to divest the State of its power to render a valid judgment. ${ }^{58}$

This understanding has characterized the Court's modern personal jurisdiction doctrine from its inception, as it has held that the Due Process Clause "does not contemplate that a state may make binding a judgment in personam against an individual or corporate defendant with which the state has no contacts, ties, or relations." 59

Applying these "settled principles" to the claims of absent, unnamed class members leads inevitably to the conclusion that to the extent such claims are unconnected with the defendant's forum state contacts, contemporary understandings of the Fourteenth Amendment's constraints on state power prevent that forum from rendering a binding, in personam judgment against the defendant on those claims. When there is confessedly no link between the claims of nonresident, absent class members and the defendant's contacts with the forum state, that forum may not exercise personal jurisdiction over the defendant with respect to those claims based merely on the defendant's relationship with third parties whose claims are connected with the forum, regardless of how similar those claims are to those brought by nonresidents. That, of course, is the core holding of BristolMyers. Given that the Fourteenth Amendment's due process constraints are the operative limitations on a federal district court's

57. Id. (quoting World-Wide Volkswagen, 444 U.S. at 292; Hanson v. Denckla, 357 U.S. 235, 251 (1958)).

58. Id. at 1780-81 (quoting World-Wide Volkswagen, 444 U.S. at 294). It is this power component of the due process constraint on a court's territorial authority that undermines any attempt to rely on the certification requirements of Rule 23 as sufficient to protect the due process rights of defendants.

59. Int'l Shoe Co. v. Washington, 326 U.S. 310, 319 (1945). 
jurisdiction to adjudicate the claims of unnamed class members, the Bristol-Myers Court's interpretation thereof and the result it compels cannot be circumvented or otherwise avoided.

\section{APPLYING THE CONSTRAINT: HOW COURTS MAY ENFORCE THE LIMITATIONS ON THEIR TERRITORIAL REACH OVER THE CLAIMS OF ABSENT CLASS MEMBERS}

Concluding that a federal court may adjudicate the claims of unnamed class members against nonresident defendants only if those claims are connected with the defendants' forum contacts does not resolve how this limitation is to be enforced. We return to the previously established proposition that at the outset of an action, a complaint filed by a plaintiff proposing to proceed on behalf of a putative class has not yet brought those claims before the court. This means that although the defendant may file a motion under Rule 12(b)(2) to dismiss the claims of the named class representative for a lack of personal jurisdiction if warranted by the facts, ${ }^{60}$ the defendant may not move to dismiss the claims of absent members of a putative, proposed class referenced in the complaint. A corollary of this principle is that a defendant's failure to seek the dismissal of the claims of absent members of a putative class in conformity with the consolidation and forfeiture principles imposed by Rule $12(\mathrm{~h}){ }^{61}$ will not constitute a waiver of the personal jurisdiction defense for those claims. ${ }^{62}$

Instead, the limits on the court's territorial jurisdiction must be factored into the court's determination of the definition of the class it will certify under Rule $23 .{ }^{63}$ In the face of an objection to the court's

60. See, e.g., Molock v. Whole Foods Mkt. Grp., Inc., 297 F. Supp. 3d 114, 126 (D.D.C. 2018) (granting a motion to dismiss under Rule 12(b)(2) for lack of personal jurisdiction with respect to claims asserted by two named class representatives).

61. FED. R. CIV. P. 12(h)(1) (providing that personal jurisdiction defenses are waived if not raised by motion under Rule 12 or in a responsive pleading filed in the absence of any Rule 12 motions).

62. This conclusion means that the decision of the district court in Cruson v. Jackson Nat'l Life Ins. Co., No. 4:16-CV-00912, 2018 WL 2937471 (E.D. Tex. June 12,2018 ) - in which it held that the defendant waived its personal jurisdiction challenge by failing to raise the challenge via a motion to dismiss before the class certification determination - was in error and should be reversed by the Fifth Circuit.

63. FED. R. CIV. P. 23(c)(1)(B). 
jurisdiction over the claims of unnamed class members having claims that are unconnected to the forum, the court should engage in the jurisdictional analysis called for by Bristol-Myers and exclude from the definition of the class those claims that cannot meet that constitutional standard. In the absence of such an objection, a court is under no obligation to exclude such claims sua sponte because the personal jurisdiction objection may be waived. ${ }^{64}$ To the extent the court-over the defendant's objection-certifies a class that includes the claims of absent class members that do not meet the applicable Fourteenth Amendment due process constraints, the defendant may seek an appeal of the certification decision ${ }^{65}$ or seek to alter or amend the class definition ${ }^{66}$ on this ground.

However, a defendant need not await the certification determination to raise personal jurisdiction problems for the claims of absent class members. Although, as previously indicated, a motion to dismiss for lack of personal jurisdiction would be out of order with respect to such claims at the outset when only a putative class is being proposed, it would very much be in order for a defendant to seek to excise allegations from a complaint that purport to include unnamed class members having non-forum-connected claims within the definition of the class. The mechanism for doing so is the motion to strike under Rule 12(f) ${ }^{67}$ A court may strike from a plaintiff's pleading any allegations that are without basis and for which there can be no recovery, particularly when retaining the allegations would be prejudicial to the defendant. ${ }^{68}$ Given that a court will ultimately be unable to adjudicate the claims of unnamed class members that are unconnected with the forum based on a lack of personal jurisdiction (if that deficiency is properly raised by the defendant), retaining those

64. Leroy v. Great W. United Corp., 443 U.S. 173, 180 (1979) (“[N]either personal jurisdiction nor venue is fundamentally preliminary in the sense that subject-matter jurisdiction is, for both are personal privileges of the defendant, rather than absolute strictures on the court, and both may be waived by the parties.").

65. FED. R. CIV. P. 23(f).

66. FED. R. CIV.P. 23(c)(1)(C).

67. FED. R. CIV. P. 12(f).

68. See, e.g.","; Mussat v. IQVIA Inc., No. 17 C 8841, 2018 WL 5311903, at *2 (N.D. Ill. Oct. 26, 2018) ("Courts will strike pleadings that are insufficient as a matter of law, meaning they bear no relation to the controversy or would prejudice the movant.") (citation and internal quotation marks omitted). See also Delta Consulting Grp., Inc. v. R. Randle Constr., Inc., 554 F.3d 1133, 1141 (7th Cir. 2009) ("The court may either strike on its own or on a motion by a party and has considerable discretion in striking any redundant, immaterial, impertinent or scandalous matter."). 
allegations in the complaint, when they cannot be properly included in the definition of the certified class, would be to keep "immaterial" and "impertinent" matter in the action.

This is the very approach taken by the judge in Mussat $v$. IQVIA Inc. ${ }^{69}$ - a case recently appealed to the Seventh Circuit. That court would be well advised to affirm. Regarding the decision of the district court in Molock v. Whole Foods Market Group, Inc., which rejected the jurisdictional challenge to the non-forum-connected claims of unnamed class members, the D.C. Circuit could affirm the denial of the motion to dismiss - given that it was premature-and remand with guidance that the district court may either entertain a motion to strike the allegations pertaining to unconnected claims of unnamed putative class members or revisit the issue when making the class certification and class definition determination. In so doing, the D.C. Circuit should announce that the standards of Bristol-Myers must be applied to such claims when properly raised on remand. An alternate approach if it is seen as futile to remand if these claims will face certain death, would be for the D.C. Circuit to construe the defendant's motion to dismiss as a motion to strike instead, and hold that the motion to strike should be granted based on Bristol-Myers.

\section{CONCLUSION}

In Bristol-Myers, the Supreme Court expressly reserved the question of "whether the Fifth Amendment imposes the same restrictions on the exercise of personal jurisdiction by a federal court." ${ }^{\text {"70 }}$ Although the Fifth Amendment permits federal courts to exercise personal jurisdiction on a nationwide basis ${ }^{71}$ federal courts are not able to exercise the jurisdiction that the Fifth Amendment would permit when they are operating under Rule 4(k)(1)(A). Until either Rule 4(k) or Rule 23 is revised-preferably by Congress-to provide for personal jurisdiction over the claims of unnamed class members not arising out of contacts with the forum, or until Congress enacts legislation to the same effect, the due process protections that class action defendants enjoy in federal court are those of the

69. 2018 WL 5311903 , at *1.

70. Bristol-Myers Squibb Co. v. Superior Ct. of Cal., S.F. Cty., 137 S. Ct. 1773, 1784 (2017).

71. See Miss. Publ'g Corp. v. Murphree, 326 U.S. 438, 442 (1946) ("Congress could provide for service of process anywhere in the United States.") See also cases cited supra in note 31 . 
Fourteenth Amendment, by operation of Rule 4(k)(1)(A). Those protections are those announced in Bristol-Myers. ${ }^{72}$

72. The Seventh Circuit panel appeared to find it alarming that this 'newly discovered rule' from Bristol-Myers would disrupt what it perceived to be decades of settled presumptions regarding jurisdiction over class actions. It is hardly unusual for Supreme Court pronouncements to have such an effect. See, e.g., Erie R.R. v. Tompkins, 304 U.S. 64 (1938) (overtuming Swift v. Tyson after a more than 100year reign); Goodyear Dunlop Tires Operations, S.A. v. Brown, 564 U.S. 915, 919 (2011) (limiting general jurisdiction to cases where the defendant may be considered "at home" despite decades of circuit precedent permitting general personal jurisdiction beyond that context in fora where a defendant's contacts were simply "continuous and systematic"). 